\title{
THE OVARY OF THE GIRAFFE, GIRAFFA CAMELOPARDALIS
}

\author{
F. I. B. KAYANJA AND L. H. BLANKENSHIP \\ Department of Veterinary Anatomy and Histology, University of Nairobi, \\ P.O. Box 30197, Nairobi, Kenya, and \\ Department of Wildlife and Fisheries Sciences, \\ Texas $A$ \& $M$ University, U.S.A.
}

(Received 24th Fuly 1972)

\begin{abstract}
Summary. The prenatal and postnatal ovaries of the giraffe were studied, using histological and ultrastructural techniques. Corpora lutea found in the ovaries of fetal and immature giraffe were not present after puberty, when a single, much larger CL was found in one of the two ovaries during pregnancy.
\end{abstract}

\section{INTRODUCTION}

The normal habitat of the giraffe is restricted to Africa. It was formerly more widespread over this continent but is now less abundant in Western Africa. In Eastern Africa, however, it still thrives on both sides of the Equator (Dorst \& Dandelot, 1970).

Amoroso \& Finn (1962) reported no remarkable features in the ovaries of a pregnant giraffe apart from the large CL and a tertiary follicle in the opposite ovary. Kellas, Van Lennep \& Amoroso (1958) noted the fact that near-term fetuses show a departure from the typical pattern of ovarian development in some species. They reported the presence of haemorrhagic follicles and a number of CL-like structures in the ovaries of fetal and new-born giraffe. Luteinization of follicular elements has also been reported in the ovaries of the human near-term fetus (Fraenkel \& Berruti, 1942; Govan \& Mukherjee, 1950). The aim of this study was to provide more information on the histology and ultrastructure of the fetal and postnatal giraffe ovary in order to throw more light on its function, especially that of the fetal and immature organ.

\section{MATERIALS AND METHODS}

The Masai giraffe, Giraffa camelopardalis tippelskirchi Matschie, was investigated on Akira Ranch about $50 \mathrm{~km}$ northwest of Nairobi in the Rift Valley of Kenya, $0^{\circ} 54^{\prime}$ to $1^{\circ} 05^{\prime}$ South and $36^{\circ} 29^{\prime}$ East. A total number of thirty-eight giraffe was collected from Akira Ranch. The animals were shot in the neck and the reproductive organs removed within $20 \mathrm{~min}$ after death. The ovaries were weighed, measured and the presence of CL or corpora albicantia observed and recorded. The same giraffe were also used for nutritional studies. 
Of the twenty-eight adult giraffe collected, only one was not pregnant (Table 1). This animal had given birth recently and uterine involution was still in progress. Eleven of the pregnant giraffe were not lactating.

Table 1. Details of the giraffe used in this investigation

\begin{tabular}{|c|c|c|c|c|c|c|}
\hline $\begin{array}{l}\text { Animal } \\
\text { no. }\end{array}$ & Date & Weight & Parity & $\begin{array}{l}\text { Nos of } C L \\
\text { and } C A\end{array}$ & $\begin{array}{l}\text { Weight of } \\
\text { ovary }(g)\end{array}$ & $\begin{array}{c}\text { Fetal length, } \\
\text { weight, and sex }\end{array}$ \\
\hline 1 & 7.7 .70 & $624 \mathrm{~A}$ & PL & $1 \mathrm{RO}$ & RO, $57 ;$ LO, 18 & $2.5 \mathrm{~cm}, 3.5 \mathrm{~g}$ \\
\hline 2 & 8.7 .70 & $617 \mathrm{~A}$ & PL & $1 \mathrm{RO}$ & $\mathrm{RO}, 66 ; \mathrm{LO}, 13$ & $1.1 \mathrm{~cm}, 0.3 \mathrm{~g}$ \\
\hline 3 & 8.7 .70 & $212 \mathrm{I}$ & $\mathrm{NP}$ & $6 \mathrm{LO}, 5 \mathrm{RO}$ & $\mathrm{RO}, 3 \cdot 1 ; \mathrm{LO}, 2.9$ & - \\
\hline 4 & 8.7 .70 & $582 \mathrm{~A}$ & PL & $1 \mathrm{LO}$ & $\mathrm{RO}, 15 ; \mathrm{LO}, 45$ & $5.3 \mathrm{~cm}, 10 \mathrm{~g}$ \\
\hline 5 & 6.10 .70 & $613 \mathrm{~A}$ & PL & $1 \mathrm{LO}$ & RO, $20 ; \mathrm{LO}, 42$ & PI \\
\hline 6 & 7.10 .70 & $721 \mathrm{~A}$ & PL & $1 \mathrm{RO}$ & $\mathrm{RO}, 30 ; \mathrm{LO}, 15$ & $48.0 \mathrm{~cm}, 3.75 \mathrm{~kg}, \mathrm{M}$ \\
\hline 7 & 8.10 .70 & $555 \mathrm{I}$ & $\mathrm{NP}$ & $2 \mathrm{LO}, 3 \mathrm{RO}$ & $\mathrm{RO}, 15 ; \mathrm{LO}, 14$ & - \\
\hline 8 & 9.10 .70 & $296 \mathrm{I}$ & NP & LO,RO* & $\mathrm{RO}, 4 \cdot 3 ; \mathrm{LO}, 3 \cdot 1$ & - \\
\hline 9 & 9.1 .71 & $625 \mathrm{~A}$ & PNL & $1 \mathrm{LO}$ & $\mathrm{RO}, 11 ; \mathrm{LO}, 56$ & PI \\
\hline 10 & 9.1 .71 & $624 \mathrm{~A}$ & $\mathrm{PL}$ & $1 \mathrm{RO}$ & RO, 32; LO, 18 & $14.5 \mathrm{~cm}, 87 \mathrm{~g}, \mathrm{~F}$ \\
\hline 11 & 9.1 .71 & $418 \mathrm{I}$ & $\mathrm{NP}$ & LO,RO* & RO, $8.0 ; L O, 7.5$ & -8 \\
\hline 12 & 10.1 .71 & $352 \mathrm{I}$ & $\mathrm{NP}$ & LO,RO* & RO, $11 ; \mathrm{LO}, 9.0$ & 一 \\
\hline 13 & 10.1 .71 & $724 \mathrm{~A}$ & PL & $1 \mathrm{RO}$ & $\mathrm{RO}, 41 ; \mathrm{LO}, 18$ & $40.0 \mathrm{~cm}, 2.1 \mathrm{~kg}, \mathrm{M}$ \\
\hline 14 & 18.4 .71 & $650 \mathrm{~A}$ & PNL & $1 \mathrm{RO}$ & $\mathrm{RO}, 67 ; \mathrm{LO}, 13$ & $2.0 \mathrm{~cm}, 1.5 \mathrm{~g}$ \\
\hline 15 & 18.4 .71 & $592 \mathrm{~A}$ & PNL & IRO & RO, $47 ; \mathrm{LO}, 16$ & $87.0 \mathrm{~cm}, 52 \mathrm{~kg}, \mathrm{~F}$ \\
\hline 16 & 19.4 .71 & $646 \mathrm{~A}$ & PL & $1 \mathrm{RO}$ & RO, $55 ;$ LO, 16 & $23 \mathrm{~cm}, 425 \mathrm{~g}, \mathrm{M}$ \\
\hline 17 & 19.4 .71 & $382 \mathrm{I}$ & $\mathrm{NP}$ & LO,RO* & $\mathrm{RO}, 7.4 ; \mathrm{LO}, 8.4$ & os \\
\hline 18 & 20.7 .71 & $668 \mathrm{~A}$ & PL & 1RO, 1CALO & & PI \\
\hline 19 & 20.7 .71 & $774 \mathrm{~A}$ & PNL & $1 \mathrm{LO}$ & - & $109 \mathrm{~cm}, 47 \mathrm{~kg}, \mathrm{M}$ \\
\hline 20 & 21.7 .71 & $338 \mathrm{I}$ & NP & LO,RO* & - & \\
\hline 21 & 21.7 .71 & $653 \mathrm{~A}$ & PL & $1 \mathrm{LO}$ & - & $5.0 \mathrm{~cm}, 9.0 \mathrm{~g}$ \\
\hline 22 & 22.7 .71 & $510 \mathrm{I}$ & $\mathrm{NP}$ & - & - & - \\
\hline 23 & 1.10 .71 & $700 \mathrm{~A}$ & PL & $1 \mathrm{RO}$ & - & $15.0 \mathrm{~cm}, 106 \mathrm{~g}, \mathrm{M}$ \\
\hline 24 & 1.10 .71 & 3711 & $\mathbf{N P}$ & LO,RO* & - & - \\
\hline 25 & 1.10 .71 & $692 \mathrm{~A}$ & PNL & $1 \mathrm{LO}$ & - & PI \\
\hline 26 & 2.10 .71 & $724 \mathrm{~A}$ & PL & 1LO, IGARO & - & PI \\
\hline 27 & 2.10 .71 & $500 \mathrm{I}$ & $\mathrm{NP}$ & $\mathrm{LO}, \mathrm{RO}^{*}$ & - & \\
\hline 28 & 2.10 .71 & $780 \mathrm{~A}$ & PL & $1 \mathrm{RO}, 1 \mathrm{CALO}$ & - & PI \\
\hline 29 & 8.2 .72 & $506 \mathrm{~A}$ & PNL & $1 \mathrm{LO}$ & - & PI \\
\hline 30 & 8.2 .72 & $792 \mathrm{~A}$ & PNL & $\mathrm{IRO}$ & $\ldots$ & $2 \cdot 6 \mathrm{~cm}, 3 \cdot 2 \mathrm{~g}$ \\
\hline 31 & 9.2 .72 & $661 \mathrm{~A}$ & PL & $1 \mathrm{RO}$ & - & $64.0 \mathrm{~cm}, 6.5 \mathrm{~kg}, \mathrm{M}$ \\
\hline 32 & 10.2 .72 & $695 \mathrm{~A}$ & PNL & $1 \mathrm{LO}$ & - & $73.3 \mathrm{~cm}, 9.5 \mathrm{~kg}, \mathrm{~F}$ \\
\hline 33 & 10.2 .72 & $686 \mathrm{~A}$ & PNL & $1 \mathrm{RO}$ & - & $86.0 \mathrm{~cm}, 17 \mathrm{~kg}, \mathrm{~F}$ \\
\hline 34 & 12.4 .72 & $723 \mathrm{~A}$ & PL & $1 \mathrm{LO}$ & - & $35.0 \mathrm{~cm}, 1.4 \mathrm{~kg}, \mathrm{M}$ \\
\hline 3.5 & 12.4 .72 & $700 \mathrm{~A}$ & NPL & - & - & \\
\hline 36 & 16.4 .72 & $724 \mathrm{~A}$ & PL & $1 \mathrm{RO}$ & - & $104 \mathrm{~cm}, 33 \mathrm{~kg}, \mathrm{M}$ \\
\hline 37 & 18.4 .72 & $662 \mathrm{~A}$ & PNL & $1 \mathrm{LO}$ & — & $17.0 \mathrm{~cm}, 115 \mathrm{~g}, \mathrm{M}$ \\
\hline 38 & 18.4 .72 & $758 \mathrm{~A}$ & PNL & IRO & - & $116 \mathrm{~cm}, 46 \mathrm{~kg}, \mathrm{~F}$ \\
\hline
\end{tabular}

$\mathrm{I}=$ immature; $\mathrm{A}=$ adult $; \mathrm{PL}=$ pregnant lactating; $\mathrm{PNL}=$ pregnant non-lactating; $\mathrm{NPL}=$ non-pregnant lactating; $\mathrm{NP}=$ non-pregnant; $\mathrm{RO}=$ right ovary; LO = left ovary; CA $=$ corpus albicans $\mathbf{M}=$ male $; \mathbf{F}=$ female; $\mathbf{P} \dot{I}=$ preimplantation.

* Number of CL not determined.

The materials for histological investigations were fixed in Bouin's fluid or formol saline and the paraffin-wax embedded sections were stained with $\mathrm{H}$ and E, Azan and the periodic acid Schiff (PAS) reaction. The diameters of the oocytes and follicles were measured in material fixed in Bouin's fluid. The ovaries of fetuses obtained from Animals 15, 19 and 38 (Table 1), were also processed for histological investigation.

The ultrastructural investigations were conducted on materials fixed initially in FG-trinitro fixative (Ito \& Karnovsky, 1968), post-fixed with osmium tetroxide and after dehydration, embedded in Epon-Araldite. The thick 
sections (1- to 2- $\mu \mathrm{m}$ ) were cut from the Epon-Araldite tissue blocks, stained with toluidine blue, and used for light microscopy. The thin sections were stained with uranyl acetate and lead citrate and examined with a Zeiss EM 9A electron microscope.

\section{RESULTS}

The average size of the fetal ovary was $2 \times 1 \times 0.8 \mathrm{~cm}$ and the mean weight was $1.6 \mathrm{~g}$ shortly before birth when the body weight was about $52 \mathrm{~kg}$. The ovary progressively increased in size after birth so that, in immature giraffe weighing up to $200 \mathrm{~kg}$, it measured $2.4 \times 1.6 \times 1 \mathrm{~cm}$ and had a mean weight of $3 \mathrm{~g}$. In immature giraffe weighing up to $400 \mathrm{~kg}$, the ovary measured $3.5 \times 2.5 \times 1.5 \mathrm{~cm}$ and had a mean weight of $10 \mathrm{~g}$. The ovary of immature giraffe with a body weight between 400 and $550 \mathrm{~kg}$ measured $4 \times 2.7 \times 1.5 \mathrm{~cm}$ and had a mean weight of $14.5 \mathrm{~g}$. The average weight of the ovary of the mature giraffe was $15.5 \mathrm{~g}$ and on average it measured $4.2 \times 3.0 \times 1.5 \mathrm{~cm}$. In this population, the female giraffe started to breed when they were just over $550 \mathrm{~kg}$ in body weight.

\section{The fetal ovary}

As was recorded by Kellas et al. (1958), Amoroso \& Finn (1962) and recently by I. W. Rowlands (personal communication), the giraffe late fetal ovary is characterized by the presence of CL and tertiary follicles (Pl. 1, Fig. 1). Two to six CL were counted in each ovary of the late fetuses. The luteal tissue was sometimes continuous with the theca interna of tertiary follicles (Pl. 1, Figs 1, 2 and 3). The CL were of variable size, sometimes over $7 \mathrm{~mm}$ in diameter, and often contained a central connective tissue core. The degree of vascularization was variable in different CL within the same ovary. The luteal cell size varied slightly within the same CL and more so between different glands from the same or different ovaries. The luteal cells were between 20 and $30 \mu \mathrm{m}$, and their nuclei between 7 and $9 \mu \mathrm{m}$, in diameter (Pl. 1, Fig. 4). Otherwise there was little histological variation between CL even from different fetuses.

The tertiary follicles consisted of small follicles of 1 to $2 \mathrm{~mm}$ in diameter, which were often viable, and much larger, frequently atretic, ones. A number of follicular cysts up to $4 \mathrm{~mm}$ in diameter were encountered in the fetal ovary. Such follicles had lost the membrana granulosa, probably owing to a sloughing process. The theca interna of atretic tertiary follicles often displayed a remarkable vascularization. Sinusoidal vessels and capillaries formed extensive networks within the theca which sometimes invaded the granulosa cell layer after rupture of the membrana propria. The richly vascularized theca was often thickened and occasionally contained enlarged and somewhat globular cells. Four tertiary follicles containing blood were encountered. Only three corpora albicantia were detected in all the fetal ovaries examined.

\section{The ovary of the immature giraffe}

Apart from their larger size, these ovaries resembled the fetal ones in that they contained small tertiary follicles and CL (PI. 1, Fig. 5). They also had large, often atretic, tertiary follicles some of which were cystic as they had lost the 
membrana granulosa. The CL again showed little histological variation within the same ovaries and between different animals. The luteal cells varied in size from 20 to $35 \mu \mathrm{m}$ in diameter (Pl. 1, Fig. 6). Each ovary usually contained three, and frequently more, CL of variable size. In general, fewer but larger CL were found in the immature ovaries compared to the fetal ones. Corpora albicantia were also uncommon in these ovaries.

\section{The adult ovary}

The most remarkable feature of the adult ovary was the absence of the CL which characterized the ovary of the late fetuses and immature giraffe. During pregnancy, one large CL was always present in one of the ovaries. The adult ovary had features similar to those described in mammalian, and especially ruminant, ovaries by Harrison (1948), Brambell (1956) and Kayanja (1969, 1972a). The tunica albuginea, lying below an attenuated germinal epithelium, was well developed and contributed to the smooth appearance of the ovarian surface.

\section{Oogenesis and follicular development}

The smallest oocytes measured $16 \mu \mathrm{m}$ in diameter. The follicular epithelium became double layered when the follicles were about $55 \mu \mathrm{m}$ in diameter. 'Thecal cones', projecting towards the ovarian surface as described by Harrison (1948) in the goat and by Kayanja (1969) in the impala, were also seen on some of the giraffe follicles.

The relative growth rate of follicles and oocytes showed the usual mammalian biphasic pattern described by Parkes (1931). The regression lines were calculated from the following formulae:

(1) $\mathrm{Y}=7 \cdot 69+0.46 \mathrm{X}$, where $\mathrm{Y}$ is the diameter of the oocyte in $\mu \mathrm{m}$ and $\mathrm{X}$ is the diameter of the follicle between 40 and $215 \mu \mathrm{m}$; and

(2) $\mathrm{Y}=103.32+0.033 \mathrm{X}$, where $\mathrm{Y}$ is the diameter of the oocyte in $\mu \mathrm{m}$ and $\mathrm{X}$ is the diameter of the follicle between 215 and $1000 \mu \mathrm{m}$.

\section{EXPLANATION OF PLATE 1}

FrG. 1. Section through the ovary of a 109-cm giraffe fetus showing CL and tertiary follicles. PAS-Orange G-Gelestin blue. $\times 4 \cdot 6$.

Fig. 2. Section through the ovary of a $109-\mathrm{cm}$ giraffe ovary showing a CL with an almost enclosed tertiary follicle. PAS-Orange G-Celestin blue. $\times 7$.

Frg. 3. A higher magnification showing the wall of a follicle as in Fig. 2. Note the continuity between the theca interna and the GL. PAS-Orange G-Gelestin blue. $\times 195$.

Frg. 4. Section showing part of a CL from the ovary of a giraffe fetus $87 \mathrm{~cm}$ in length. Toluidine blue. $\times 200$.

FIG. 5. Section through an ovary of an immature giraffe (Animal 12, Table 1). Note the CL and tertiary follicles. Azan. $\times 3 \cdot 0$.

Frg. 6. Section through a CL from an immature giraffe (Animal 24, Table 1). Note the lipid droplets. Toluidine blue. $\times 650$.

Frg. 7. Section through a preimplantation GL. Toluidine blue. $\times 300$.

Fig. 8. Section through a CL from a giraffe carrying a 15-cm fetus (Animal 23, Table 1). Toluidine blue. $\times 200$. 

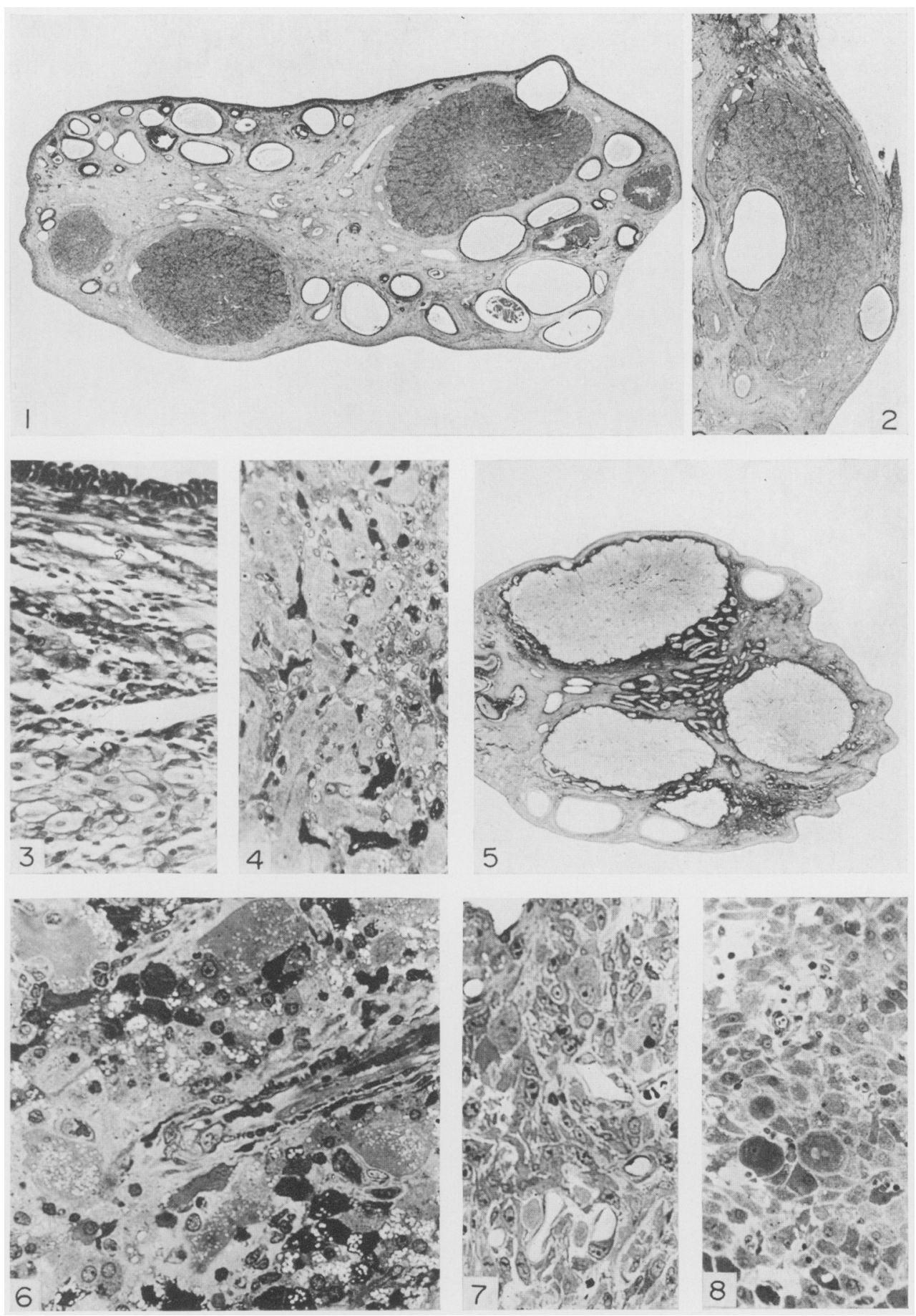
PI.AYI: 2
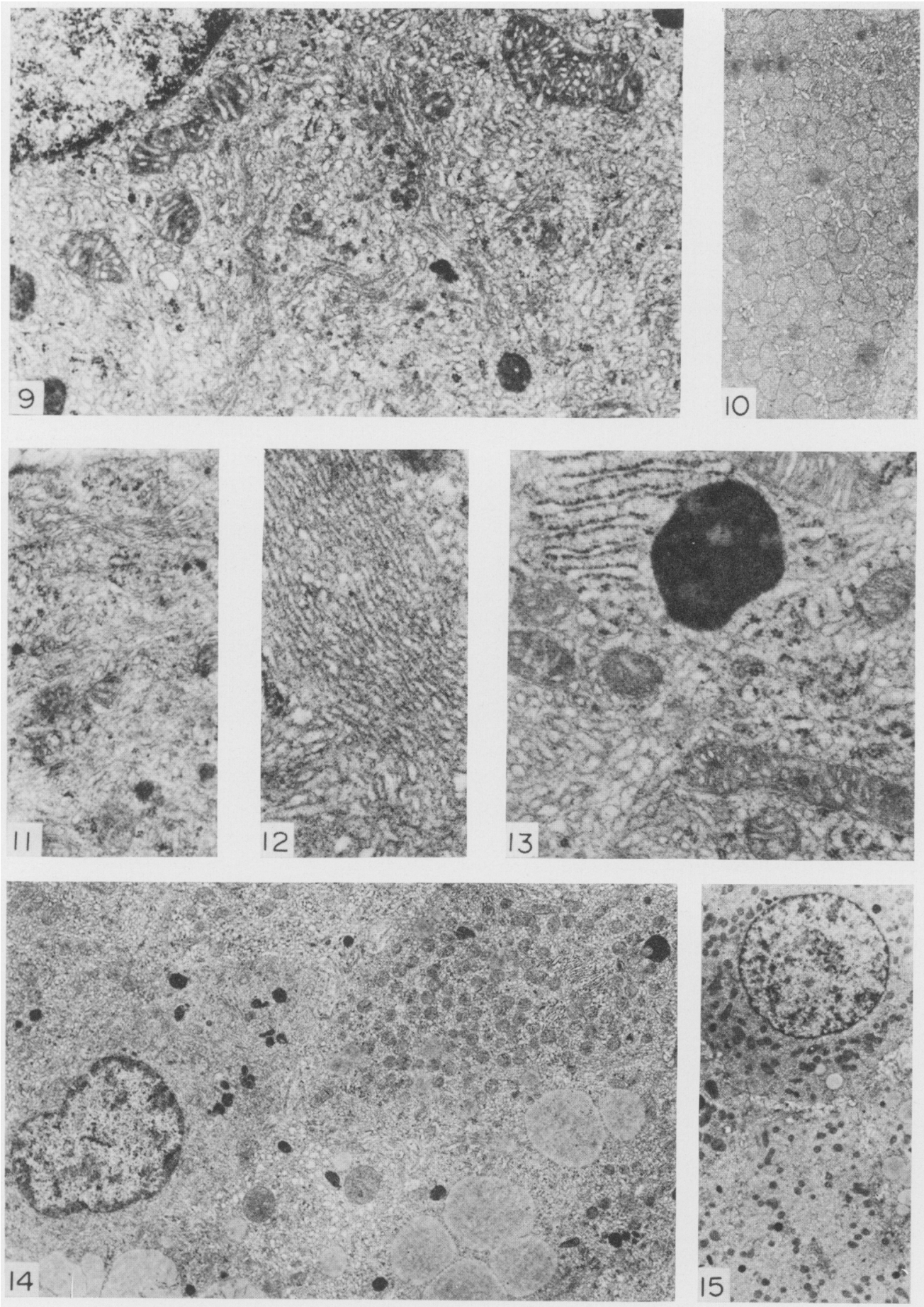


\section{Follicular atresia}

This process was observed in fetal, immature and adult giraffe ovaries. Loss of the membrana granulosa by sloughing, leading to the formation of follicular cysts was a common occurrence. Some of the cysts were over $10 \mathrm{~mm}$ in diameter. In medium-sized follicles, the richly vascularized theca interna sometimes invaded the granulosa cell layer. This was accompanied by folding of the follicular wall. The invading theca was usually thickened. The process of atresia eventually led to the collapse of the follicle.

\section{The corpus luteum}

The CL in the fetal ovaries usually contained more connective tissue than those in the ovaries of immature giraffe. The connective tissue content was, however, variable in different CL and especially when they were from different ovaries. Thin septa of connective tissue containing mainly stromal fibroblasts and collagenous fibres passed from the periphery towards the centre of the gland. The luteal cells were grouped together between the septa. It is likely that the septa indicated the original invasion path of the thecal tissue during glandular formation. The connective tissue septa were less obvious in the CL in the immature giraffe ovaries (Pl. 1, Figs 1 and 5). The glandular tissue masses observed in fetal and immature giraffe ovaries had the histological features of CL (Pl. 1, Figs 1 to 6). More lipid droplets were identified in the luteal cells of the immature giraffe. The luteal cells, especially when $>25 \mu \mathrm{m}$ in diameter, often contained faint but distinctly granular PAS-positive material around or to one side of the nucleus.

\section{The corpus luteum of pregnancy}

In twenty-seven pregnant giraffe, the CL was found in the right ovary in sixteen animals and in the left ovary in eleven animals. During early pregnancy before implantation, there was a corpus albicans in the opposite ovary as in Animals 18, 26 and 28 (Table 1). In these three animals, uterine involution was still in progress indicating that parturition had taken place only a few days before the animals were culled.

The CL of pregnancy was large, varying from 3 to $5 \mathrm{~cm}$ in diameter when fully formed, and persisted throughout pregnancy. The ovary containing the CL was heaviest during early pregnancy (Table 1 ). The ovarian weight showed a

\section{EXPLANATION OF PLATE 2}

FIG. 9. Electron micrograph showing part of a luteal cell from a GL of a giraffe carrying a 109 -cm fetus. $\times 16,000$.

Fig. 10. Electron micrograph showing part of a mitochondria-rich luteal cell from a GL of an immature giraffe (Animal 24, Table 1).

FIG. 11. The peripheral region of a luteal cell taken from a preimplantation CL. Note the smooth endoplasmic reticulum. $\times 19,600$.

FIG. 12. Electron micrograph showing smooth endoplasmic reticulum in a luteal cell from a CL of a giraffe carrying a $2 \cdot 6-\mathrm{cm}$ fetus (Animal 30, Table 1). $\times 24,500$.

Fig. 13. Part of a luteal cell from a CL of a giraffe carrying a $35-\mathrm{cm}$ fetus (Animal 34, Table 1). $\times 21,700$.

Fig. 14. Luteal cells from a CL of an immature giraffe (Animal 24, Table 1). $\times 3360$.

Fig. 15. Luteal cells from a GL of a giraffe fetus measuring $109 \mathrm{~cm}$ crown-rump length. $\times 3350$. 
tendency to drop towards the end of gestation as did the diameter of the CL it contained.

The developing luteal cells measured from 19 to just over $20 \mu \mathrm{m}$ in diameter in the earliest preimplantation CL obtained (Pl. 1, Fig. 7). The fully formed cells measured between 25 and $35 \mu \mathrm{m}$ in diameter. They contained lipid droplets and the eccentrically located nucleus had one or two prominent nucleoli. There was a diversity of cell size within the same gland but, in general, large and small cells were recognizable especially during early pregnancy (Pl. 1, Fig. 8). A faint granular PAS-positive material resistant to diastase digestion was demonstrated in some cells in all fully formed CL. The material was frequently arranged to one side of the nucleus but was less prominent than was reported in the impala by Kayanja (1969).

\section{Ultrastructure}

The nucleus contained small clumps of heterochromatin scattered in the nucleoplasm. Peripheral heterochromatin and well-developed nucleoli were characteristic features. As the cells became fully luteinized, the heterochromatin content of the nucleus was reduced.

The mitochondrial profiles were typically rod-shaped or filamentous although on some occasions they were oval or round (Pl. 2, Fig. 9). The mitochondria were most pleomorphic in the earliest preimplantation CL. Belt, Cavazos, Anderson \& Kraeling (1970) observed that the mitochondria were mostly circular or oval in pig luteal cells and also that they had tubular cristae. Human luteal cells had both tubular and lamellar cristae according to Adams \& Hertig (1969). In the luteal cells of the giraffe, the infoldings of the inner limiting membrane of the mitochondria had tubular profiles with only occasional lamellae (Pl. 2, Fig. 9). In most cells, the smooth endoplasmic reticulum was clearly more prominent than the mitochondria. Some cells, however, contained a surprising amount of mitochondria, often accounting for over $75 \%$ of the extranuclear cytoplasmic compartment (Pl. 2, Fig. 10). In such cells, the mitochondria had mostly circular or oval shapes.

As in the other steroid production cells (Christensen \& Gillim, 1969), the smooth endoplasmic reticulum (SER) was better developed than the rough endoplasmic reticulum (RER) in the fully grown giraffe luteal cells. In the earliest preimplantation CL, however, the SER was sometimes superseded by the RER. In such cells, the developing SER formed exceedingly narrow (100 to $150 \AA$ wide) tubules, usually arranged as parallel bundles amongst the mitochondria and the few lipid droplets present (Pl. 2, Fig. 11). This was observed in the GL obtained from Animals 18, 26 and 28 (Table 1). In the fully grown luteal cells, the SER, as random tubules, extended over the largest part of the cell although fenestrated tubules were identified on some occasions (Pl. 2, Fig. 12). Free ribosomes were only occasionally identified between the random tubules of SER.

The RER, which was well developed in the earliest preimplantation CL, became less prominent with the development of the luteal cells. It was present in all luteal cells as networks of meshed tubules although cisternae were also seen ( $\mathrm{Pl}$. 2, Fig. 13). The tubules of the RER were continuous with those of the SER. 
The Golgi complex was more frequently encountered in the cells of the preimplantation CL. It consisted of several elements each made up of stacks of four to seven cisternae (Pl. 2, Fig. 9). The cisternae had the characteristic terminal dilatation and many membrane-bounded vesicles, including coated ones, were present in the vicinity. The curvature of the elements of the Golgi complex was variable and some were almost straight. The curvature, when pronounced, showed no orientation with regard to the cell surface. In the fully formed luteal cells with abundant SER, the Golgi complex was more difficult to locate. It was, however, easily detected in cells with many mitochondria.

Dense bodies and lysosomes were encountered in the cytoplasm and especially near the nucleus. In general, the giraffe luteal cells contained less dense bodies than were recorded in the impala by Kayanja (1972b). There was no significant increase in dense body numbers towards the end of gestation. Lipid droplets were present in the giraffe luteal cells. Only a few were present even in the largest cells of the early preimplantation CL. There was an increase of lipid droplet content towards the end of gestation.

The ultrastructural features of CL found in the fetal and immature giraffe ovaries were generally similar to those just described for the gland during pregnancy (Pl. 2, Figs 14 and 15). The former GL, however, contained more lipid droplets. In the CL of pregnancy, the lipid droplets ranged from 0.80 to just over $2.0 \mu \mathrm{m}$ in diameter. They were often much larger, sometimes over 3.0 $\mu \mathrm{m}$ in diameter, in the fetal and immature giraffe CL. More mitochondria-rich cells were also found in the latter CL. The elements of the Golgi complex were also more easily detected and the RER tended to form cisternae. More dense bodies were present in these CL.

The luteal cells, especially during early pregnancy, were separated from each other by extracellular spaces of varying dimensions. Some collagen fibres, fibroblasts and many capillaries with a continuous endothelium were found in these spaces. Sometimes well-developed microvilli from the luteal cells extended into the extracellular spaces. Where the plasma membranes of adjacent luteal cells lay against one another, they were separated by a gap of about $200 \AA$ in width. Intercellular junctions were restricted to small plaques where the outer leaflets of adjacent cell membranes were closely apposed. The plaques were best developed in the preimplantation CL. The cells in these glands were more irregular in shape with cytoplasmic extensions projecting away from the nucleus into the abundant extracellular space. The plaques were consistently seen where the extensions of adjacent luteal cells approached each other.

\section{DISGUSSION}

It is likely that there is a post-partum oestrus in the giraffe, the exact timing of which was not determined in this investigation. This suggestion is based on the finding of a developing CL in association with a corpus albicans before complete uterine involution had been achieved in Animals 18, 26 and 28 (Table 1). The giraffe was normally lactating at this time. Lactation usually lasted until the female giraffe was carrying a fetus of about $70 \mathrm{~cm}$ in length. There was usually 
a resting period before the subsequent parturition which occurred when the fetus was about $110 \mathrm{~cm}$ in length.

Perry \& Rowlands (1962) suggested that the large tertiary follicles in fetal ovaries gave rise to the CL-like masses. The present investigation supports this proposition and also indicates that the theca interna is most vital in this process. The histological and ultrastructural appearance of the glandular masses confirm they are CL and that they are probably capable of steroid hormone secretion. Even in the largest immature giraffe, the CL never attained the size of the gland in pregnancy. It is unlikely that there is a quick turnover of these CL by formation and degeneration as corpora albicantia were relatively uncommon in fetal and immature giraffe ovaries. Unfortunately, the present study could not confirm that this is a continuous process.

Eckstein (1962) and Amoroso \& Finn (1962) observed that the fetal giraffe ovary displayed considerable sensitivity to hormonal stimuli. Fetal luteinization is likely to be due to exposure to circulating hormones of pregnancy. This assumption makes it even more intriguing that CL persist in the ovaries of immature giraffe. It does not, however, necessarily invalidate the suggestion that circulating maternal hormones are involved in fetal luteinization but indicates that the problem is more complex than was anticipated. It is a challenge to explain why the multiple CL are absent from the giraffe ovary after puberty. The factors responsible for this change must be related to those which precipitate puberty. These factors are unfortunately not yet clearly understood.

As in the Uganda kob (Buechner, Morrison \& Leuthold, 1966) and the impala (Kayanja, 1969), ovulation appears to occur at random in the left and right ovaries of the giraffe, though the presence in early pregnancy of a CL in association with a corpus albicans in the opposite ovary does indicate some alternation.

The CL of pregnancy persists throughout gestation and is usually largest during the first third of pregnancy. Preimplantation CL of about $3 \mathrm{~cm}$ in diameter had cells which lacked the elaborate SER typical of steroid-secreting cells. The process of full luteinization, therefore, appears to lag behind the rapid increase in glandular size in the giraffe.

Adams \& Hertig (1969) and Kayanja (1972b) recorded a 'compartmentalization' of the luteal cell cytoplasm in the human and the impala, respectively. This is not so clearly defined in the giraffe. As in the impala (Kayanja, 1972b), dense bodies lie near the nucleus and correspond to the PAS-positive material seen by light microscopy. There are relatively few dense bodies in the giraffe luteal cells and the number does not seem to increase towards the end of gestation as in the impala.

\section{AGKNOWLEDGMENTS}

We wish to thank Mr B. Gaymer, Manager, Akira Ranch, for his co-operation and making this project possible. We are indebted to Dr G. R. Field for his advice and encouragement. Our most grateful thanks are due to Miss J. Jhite and $\mathrm{Mr}$ E. Njogu for technical assistance as well as Mr S. Masheti and personnel of the Wildlife Veterinary Laboratory, Kabete, for field assistance. 
This project was conducted on funds made available by the Caesar Kleberg Research Programme in Wildlife Ecology, the Rockefeller Foundation and the University of Nairobi.

\section{REFERENGES}

AdAms, E. G. \& HeRtig, A. T. (1969) Studies on the human corpus luteum. II. Observations on the ultrastructure of the luteal cells during pregnancy. F. Cell Biol. 41, 716.

Amoroso, E. G. \& Fins, G. A. (1962) Ovarian activity during gestation, ovum transport and implantation. In: The Ovary, chap. 9, p. 451. Ed. S. Zuckerman. Academic Press, New York and London.

Belt, W. D., Gavazos, L. F., Anderson, L. L. \& Kraeling, R. R. (1970) Fine structure and progesterone levels in the corpus luteum of the pig during pregnancy and after hysterectomy. Biol. Reprod. 2, 98.

Brambell, F. W. R. (1956) Ovarian changes. In: Marshall's Physiology of Reproduction, Vol. 1, chap. 5. Ed. A. S. Parkes. Longmans Green, London.

Buechner, H. K., Morrison, A. J. \& Leuthold, W. (1966) Reproduction in Uganda kob with special reference to behaviour. Symp. zool. Soc. Lond. 15, 69.

Christensen, K. A. \& Gillim, S. W. (1969) The correlation of fine structure and function in steroid secreting cells, with emphasis on those of the gonads. In: The Gonads. Ed. K. W. McKerns, Appleton Century Crofts, New York.

Dorst, J. \& DANDELot, P. (1970) A field guide to the larger mammals of Africa. Collins, London.

Eckstern, P. (1962) Ovarian physiology in the non-pregnant female. In: The Ovary, chap. 6, p. 311. Ed. S. Zuckerman. Academic Press, New York and London.

Fraenkel, L. \& Berruti, P. G. (1942) Thecal proliferation in the ovary of the infant; comparison with hyperthecosis in the adult. Archos Soc. Biol. Montev. 10, 267.

Govan, A. D. T. \& Mukherjee, C. L. (1950) Maternal toxaemia and foetal ovarian activity. $\mathcal{J}$. Obstet. Gynaec. Br. Emp. 57, 525.

HARRISON, R.J. (1948) The changes occurring in the ovary of the goat during the estrous cycle and in the early pregnancy. F. Anat. 82, 21.

Ito, S. \& Karnovsky, M. J. (1968) Formaldehyde-glutaraldehyde fixatives containing trinitro compounds. 7. Cell Biol. 39, 168a.

Kayanja, F. I. B. (1969) The ovary of the impala, Aepyceros melampus (Lichtenstein, 1812). 7. Reprod. Fert. Suppl. 6, 311.

Kayanja, F. I. B.(1972a) Reproduction in antelopes. Reproduction in the female impala (Aepyceros melampus Lichtenstein, 1812). Vol. 1 of East African Monographs in Biology. Ed. T. R. Odhiambo. East African Literature Bureau, Nairobi

Kayanja, F. I. B. (1972b) The ultrastructure of the corpus luteum of the impala. Aepyceros melampus (Lichtenstein, 1812). Anat. Anz. Bd. 132, S. 123.

Keldas, L. M., Van LenNeP, E. W. \& Amoroso, E. G. (1958) Ovaries of some foetal and prepubertal giraffe (Giraffa camelopardalis, Linnaeus). Nature, Lond. 181, 487.

Parkes, A. S. (1931) The reproductive process of certain mammals. II. The size of the Graafian follicle at ovulation. Proc. R. Soc. B. $109,185$.

Perry, J. S. \& Rowlands, I. W. (1962) The ovarian cycle in vertebrates. In: The Ovary, chap. 5, p. 275. Ed. S. Zuckerman. Academic Press, New York and London. 